\title{
MONITORING THE ARTIFICIAL SPACE OBJECTS WITH UKRAINIAN NETWORK OF OPTICAL STATIONS
}

\author{
Ya.O. Romanyuk ${ }^{1}$, O.V. Shulga ${ }^{2}$, L.S. Shakun ${ }^{3}$, N .I. Koshkin ${ }^{3}$, Ye.B. Vovchyk ${ }^{4}$, A.I. Bilinsky ${ }^{4}$,
} Y.S. Kozyryev ${ }^{2}$, M.O. Kulichenko ${ }^{2}$, V.F. Kriuchkovsky², V.I. Kashuba ${ }^{3}$, E.A. Korobeynikova ${ }^{3}$, S.M. Melikyants ${ }^{3}$, S.L. Strakhova ${ }^{3}$, S.S. Terpan ${ }^{3}$, T.A. Golubovskaya ${ }^{3}$, K.P. Martyniuk-Lototskiy ${ }^{4}$, R.T. Nogacz ${ }^{4}$, V.P. Epishev ${ }^{5}$, V.I. Kudak ${ }^{5}$, I.F. Neubauer ${ }^{5}$, V.M. Perig ${ }^{5}$, V.I. Prysiazhnyi ${ }^{6}$, A.P. Ozeryan ${ }^{6}$, O.M. Kozhukhov ${ }^{6}$, D.M. Kozhukhov ${ }^{6}$, Yu.M. Ivaschenko ${ }^{7}$

${ }^{1}$ Main Astronomical observatory of NASU, Kyiv, Ukraine, romanyuk@mao.kiev.ua

${ }^{2}$ Research Institute "Mykolaiv Astronomical Observatory", Mykolaiv, Ukraine, shulga@nao.nikolaev.ua

${ }^{3}$ Research Institute “Astronomical Observatory” of Odessa I.I. Mechnikov National University, Odessa, Ukraine,nikkoshkin@yahoo.com

${ }^{4}$ Astronomical Observatory, Ivan Franko National University of Lviv, Lviv, Ukraine, evavovchyk@ukr.net, andrii.bilinskyi@lnu.edu.ua

${ }^{5}$ Laboratory of Space Research, Uzhhorod National University, Uzhhorod, Ukraine, lkd.uzhgorod@gmail.com

${ }^{6}$ National Space Facilities Control and Test Center, Kyiv, Ukraine, a.m.kozhukhov@gmail.com

${ }^{7}$ Andrushivka Astronomical Observatory, Andrushivka, Ukraine,aoa.ivaschenko@gmail.com

ABSTRACT. The article describes the successes and challenges of the Ukrainian network of optical stations (UMOS) in recent years in the field of astrometric observations of artificial space objects both in low-Earth orbit (LEO) and geostationary Earth orbit (GEO). UMOS was established in 2012 as a joint partnership of organizations interested in satellite observations for scientific purposes and practical near Earth space monitoring. The main purpose of the UMOS has been (and still is) to combine scientific and technical means with regular optical (positional and / or non-positional) observation. The short list of equipment of the UMOS members are given in the tables. The programs for observations, used methods and obtained results are described in the paper. In conclusion, the advantages of observations of artificial space objects by means of a network are summarized. The experience of UMOS and main results obtained by UMOS can be considered as the first step to create the SSA system of Ukraine.

АНОТАЦІЯ. У статті описано успіхи та виклики у діяльності української мережі оптичних станцій (УМОС) за останні роки у сфері астрометричних спостережень штучних космічних об'єктів, як на низькій орбіті над Землею (ННО), так і на геостаціонарній орбіті (ГСО). Необхідно відзначити, що з моменту запуску першого супутника в 1957 році багато космічних апаратів, а також тисячі відпрацьованих ступенів ракет, частини корпусів та інше перебувають в навколоземному просторі. Це створює напруженість в ближньому космічному просторі. А крім того багато об'єктів, які запущені в ближній космічний простір мають подвійне призначення, що становить загрозу безпеці країни. Тому моніторинг космічного простору стає надзвичайно важливою задачею, як 3 точки зору захисту своїх космічних апаратів від зустрічі з космічних сміттям так i 3 військової точки зору. Більшість країн, які піклуються про безпеку своїх супутників та своєї території, створюють системи космічної ситуаційної обізнаності (CКО) та проводять моніторинг ближнього космічного простору. На даний час і в Україні також є потреба у створенні такої системи. Досвід УМОС та основні результати, отримані мережею, можна вважати першим кроком до створення СКО України.

УМОС було створено у 2012 році як спільне партнерство організацій, зацікавлених у супутникових спостереженнях для наукових цілей та практичному моніторингу навколоземного космічного простору. Основною метою УМОС було (і залишається на сьогодні) поєднання розробки та вдосконалення науково-технічних засобів із регулярними оптичними (позиційним та/або непозиційними) спостереженнями. Короткий перелік обладнання, яким здійснюють спостереження штучних космічних об'єктів члени УМОС, наведено в таблицях. У статті перераховані програми спостережень, використані методи та отримані результати. На закінчення узагальнено переваги спостережень штучних космічних об'єктів за допомогою мережі.

Key words: artificial space objects; optical observations. 


\section{Introduction}

Since the launch of the first satellite in 1957, many spacecrafts, along with thousands of spent rocket stages, hull parts, and others, have been in near-Earth space. Taken together, active spacecrafts and space debris have become an integral part of outer space. According to estimates by experts from the European Space Agency (ESA) (ESA Report, 2021), 6,050 spacecraft launches have launched 56,450 spacecrafts into orbit, about 28,160 of them remain in space. It covers objects of approximately $5-10 \mathrm{~cm}$ or more in low-Earth orbit (LEO) and from $30 \mathrm{~cm}$ in geostationary orbits (GEO).

Space debris poses a threat to active spacecrafts. However, one should also consider the purpose of the launches itselves. Many spacecrafts have a dual purpose, in parallel with scientific and practical tasks, they perform military functions. And such satellites are controlled by the world's leading states because they pose a threat to the country's security. That's why the relevance of space monitoring is becoming extremely important in our time. Most of the countries that care about their security create systems of space situational awareness (SSA) (SSA, 2017; Vallado \& Griesbach, 2011). At the moment, there is a need for Ukraine to create such a system as well.

\section{UMOS - Ukrainian Network of Optical Stations}

At the very beginnings in 2012 the UMOS (from Ukrainian acronym - УМOC, Українська мережа оптичних станцій дослідження навколоземного космічного простору) counted 7 organisations (UMOS site). Now there are same number of organizations (Shulga et al., 2015), but two stations (Alchevsk, Evpatoria) are out of work because of the russian agression on Ukraine. The Andrushivka observatory and the National Space Facilities Control and Tests Center of State Space Agency of Ukraine (NSFCTC) joined UMOS. It should be noted that two stations from the NSFCTC (Dunaivtsi and Evpatoria) were included in the UMOS from the first days.

So, the UMOS is an alliance of Ukrainian institutional research observatories and optical facilities of State Space Agency. Its strategic tasks include near-Earth space research (from LEO to GEO and HEO), and the studies of motion of selected objects by development and improvement of theory, models and algorithms. Also it is aimed at addressing tactical problems like assistance in Ukrainian or international space launches. The UMOS's field of view covers large area of space, its facilities arrangement allows to carry out the observations of some consecutive passes of LEO satellites, as well as synchronous (Koshkin et al., 2020) and complementing observations.

The main goal of UMOS was (and still is) to unite scientific and technical means of different stations and to conduct regular optical (positional and/or nonpositional) observations of the objects in near Earth space.

\subsection{UMOS Equipment}

At present observations are carried out (or could be carried out on demand) by 6 telescopes of Astronomical
Observatory of Odessa I.I. Mechnikov National University (AO ONU) (Kaminski, 2017; Koshkin, 2017; Troianskyi, 2019; Koshkin, 2020), 5 telescopes of the Research Institute "Mykolaiv Astronomical Observatory" (RI MAO) (Sybiryakova at al., 2017; Patent 116724; Patent 118001, 2017), 4 telescopes of Astronomical Observatory of Ivan Franko National University of Lviv (AO LNU) (Koval'chuk et al., 2017; Patent 116522, 2017), 2 telescopes LSR Uzhhorod National University (LSR UzhNU), 2 telescopes Andrushivska Astronomical Observatory (AAO), 2 telescope Main Astronomical observatory of NASU (MAO NASU) and 4 telescopes of NSFCTC (Kozhukhov et al., 2019). All telescopes are equipped with various CCD and CMOS cameras.

The detailed information of the telescopes and the receiving cameras are given below in the Table 1.

\subsection{Space Objects for Observations and Programs}

There are different kind of space objects in the UMOS surveillance program, but also different programs are considered. At present in the list of objects for observation are more than 700 ones. The oldest object is Vanguard launched in 1958, and the most recent object is Cosmos 2549 launched in 2021. From this list one could choose objects which will be visible at the night.

There are programs for:

- observing low-orbit objects and geostationary objects;

- observing both active satellites and space debris;

- monitoring of satellites launches and re-entries;

- measurements of satellites positions for stereo pairs and clusters.

The UMOS can decide scientific, practical and military tasks observing satellites appointed for different purposes. Every six months the list of the objects for observations can be corrected considering the set tasks. Sometimes there arise a special task, then UMOS members are working in a special regime.

\subsection{Observational Methods}

Various methods of observation are used depending of the telescopes and receiving devices:

- Differential method with CCTV camera + mechanical tracking -- used in Odessa and Lviv for low orbit objects observation.

- Method of frames accumulation with CCTV camera + stare telescope - images of an object and a star are formed from a single video stream (designed in Mykolaiv (Kozyrev et al., 2007), and used in Kyiv, Lviv, Uzhhorod for LEO observation).

- Combined method with TDI full CCD + stare telescope images of the object and stars are formed with different modes and angles of rotation of the CCD. (designed in Mykolaiv, and used in Odessa, Kyiv for LEO, MEO, GS observation).

For processing and astrometric reductions of observed data mostly are used Astrometrica software (Astrometrica site), as well as its own original software for LEO observations (Shakun \& Koshkin, 2014). 
Table 1: Main characteristics of telescopes of UMOS

\begin{tabular}{|c|c|c|c|c|c|c|c|c|c|c|}
\hline $\begin{array}{l}\text { Stations, } \\
\text { telescopes }\end{array}$ & $\begin{array}{c}\text { Aper- } \\
\text { ture, } \\
\text { cm }\end{array}$ & \begin{tabular}{|c|} 
Focal \\
length, \\
$\mathbf{m}$
\end{tabular} & Camera (chip) & Size, pix. & $\begin{array}{l}\text { Pixel size, } \\
\mu \mathrm{m}\end{array}$ & $\begin{array}{l}\text { Scale without } \\
\text { bining ("/pix) }\end{array}$ & FoV $\left(\operatorname{deg}^{2}\right)$ & Mount & $\begin{array}{l}\text { Slew } \\
\text { rate, } \\
\text { deg/s }\end{array}$ & $\begin{array}{l}\text { Track- } \\
\text { ing }\end{array}$ \\
\hline $\begin{array}{c}\text { NSFCTC: } \\
\text { WFoV } \\
\text { telescope QOS }\end{array}$ & 30 & 0.3 & $\begin{array}{l}\text { QHY-174M GPS (Sony 1/1.2" } \\
\text { CMOS IMX174LU / IMX174LQJ) }\end{array}$ & $1936 \times 1216$ & 5.86 & 4.01 & $\begin{array}{c}2.89 \\
\left(130^{\prime} \times 80^{\prime}\right)\end{array}$ & $\begin{array}{c}\text { Equatorial } \\
\text { with two } \\
\text { parallel } \\
\text { lenses }\end{array}$ & 2.5 & yes \\
\hline $\begin{array}{c}\text { NSFCTC: } \\
\text { NFoV } \\
\text { telescope QOS }\end{array}$ & 50 & 8.0 & $\begin{array}{c}\text { FLI ML } 16070 \text { (Interline ON Semi } \\
\text { KAI-16070) + UBVRI filters }\end{array}$ & $4864 \times 3232$ & 7.4 & 0.28 & $\begin{array}{c}0.039 \\
\left(14.5^{\prime} \times 9.5^{\prime}\right)\end{array}$ & & & \\
\hline $\begin{array}{l}\text { NSFCTC: } \\
\text { OEOS-1 }\end{array}$ & 50 & 1.9 & \begin{tabular}{|c|} 
WFoV camera: FLI ML 16070 \\
(Interline CCD ON Semi KAI- \\
16070) \\
NFoV camera: QHY-174M GPS \\
(Sony 1/1.2" CMOS IMX174LL / \\
IMX174LQJ)
\end{tabular} & $\begin{array}{l}\text { WFoV cam: } \\
4864 \times 3232 \\
\text { NFoV cam: } \\
1936 \times 1216\end{array}$ & $\begin{array}{l}\text { WFoV cam: } \\
7.4 \\
\text { NFoV cam: } \\
5.86\end{array}$ & $\begin{array}{c}\text { WFoV camera: } \\
0.80 \\
\text { NFoV camera: } \\
0.64\end{array}$ & $\begin{array}{l}\text { WFoV cam: } \\
0.774 \\
\left(64.8^{\prime} \times 43^{\prime}\right) \\
\text { NFoV cam: } \\
0.075 \\
\left(20.7^{\prime} \times 13^{\prime}\right)\end{array}$ & $\begin{array}{l}\text { Equatorial } \\
\text { fork }\end{array}$ & Up to 5.0 & yes \\
\hline $\begin{array}{l}\text { NSFCTC: } \\
\text { OEOS -2 }\end{array}$ & 30 & 0.3 & $\begin{array}{c}1 \text { camera: QHY-174M GPS (Sony } \\
\text { 1/1.2" CMOS IMX174LU / } \\
\text { IMX174LQJ) } \\
2 \text { camera: FLI ML } 16070 \\
\text { (Interline ON Semi KAI-16070) }\end{array}$ & $\begin{array}{l}1 \text { camera: } \\
1936 \times 1216 \\
2 \text { camera: } \\
4864 \times 3232\end{array}$ & $\begin{array}{c}1 \text { camera: } \\
5.86 \\
2 \text { camera: } 7.4\end{array}$ & $\begin{array}{c}1 \text { camera: } 4.01 \\
2 \text { camera: } \\
5.1\end{array}$ & $\begin{array}{l}1 \text { camera: } \\
2.89 \\
\left(130^{\prime} \times 80^{\prime}\right) \\
2 \text { camera: } \\
\sim 31.74 \\
\left(6.9^{\circ} \times 4.6^{\circ}\right)\end{array}$ & $\begin{array}{c}\text { Modified } \\
\text { German with } \\
\text { Direct Drive }\end{array}$ & Up to 10 & yes \\
\hline $\begin{array}{c}\text { AO ONU: } \\
\text { KT-50 } \\
\text { (Odessa) } \\
\end{array}$ & 50 & 2.0 & CCTV Watec-902H2 & $752 \times 582$ & $8.6 \times 8.3$ & 0.85 & $\begin{array}{c}0.0252 \\
\left(10.8^{\prime} \times 8.4^{\prime}\right)\end{array}$ & Alt-azimuth & 4.0 & $\begin{array}{c}\text { Semi- } \\
\text { automati } \\
\mathrm{c}\end{array}$ \\
\hline $\begin{array}{c}\text { AO ONU: } \\
\text { Schmidt } \\
\text { (Kryzhanivka) }\end{array}$ & $\begin{array}{c}21.92 / 2 \\
7.125\end{array}$ & 0.44 & CCTV Watec-902H2 & $752 \times 582$ & $8.6 \times 8.3$ & 3.87 & $\begin{array}{c}0.52 \\
\left(50^{\prime} \times 37.4^{\prime}\right)\end{array}$ & Equatorial & 1.0 & No \\
\hline $\begin{array}{l}\text { AO ONU: } \\
\text { OMT-800 } \\
\text { (Mayaky) }\end{array}$ & 80 & 2.14 & $\begin{array}{l}\text { FLI ML09000 (Full frame ON } \\
\text { Semi KAF-9000) }\end{array}$ & $3056 \times 3056$ & 12 & 1.16 & $0.97\left(59^{\prime} \times 59 '\right)$ & Equatorial & 0.75 & $\begin{array}{c}\text { Yes } \\
\text { (MEO, } \\
\text { GEO) } \\
\end{array}$ \\
\hline $\begin{array}{l}\text { AO ONU: } \\
\text { Cassegrain } \\
\text { (Mayaky) }\end{array}$ & 48 & 11.05 & $\begin{array}{c}\text { Single channel photometer PMT } \\
\text { (BVR) }\end{array}$ & - & - & - & - & Equatorial & & No \\
\hline $\begin{array}{l}\text { AO ONU: } \\
\text { KTS(Mayaky) }\end{array}$ & 23 & 1.52 & $\begin{array}{c}\text { Apogee Alta U9000 (Kodak KAF- } \\
\text { 09000). }\end{array}$ & $3056 \times 3056$ & 12 & 1.62 & $\begin{array}{c}1.89\left(82.5^{\prime} \times\right. \\
\left.82.5^{\prime}\right)\end{array}$ & Alt-azimuth & 2.0 & $\begin{array}{l}\text { Yes } \\
\text { (LEO, } \\
\text { GEO) }\end{array}$ \\
\hline $\begin{array}{l}\text { AO ONU: } \\
\text { TAL-250K } \\
\text { (Mayaky) } \\
\end{array}$ & 25 & 2.13 & FLI ML09000 & $3056 \times 3056$ & 12 & 1.16 & $0.3\left(33^{\prime} \times 33^{\prime}\right)$ & Equatorial & 2.0 & $\begin{array}{c}\text { Yes } \\
\text { (MEO, } \\
\text { GEO) }\end{array}$ \\
\hline $\begin{array}{c}\text { RI MAO: } \\
\text { KT-50 } \\
\text { (MOBITEL) }\end{array}$ & 50 & 3.0 & $\begin{array}{c}\text { Apogee Alta U9 (ON Semi KAF- } \\
\text { 09000) }\end{array}$ & $3056 \times 3056$ & 12 & 0.8 & $\begin{array}{c}0.49 \\
(0.7 \times 0.7)^{\circ}\end{array}$ & Alt-azimuth & 2 & No \\
\hline $\begin{array}{l}\text { RI MAO: } \\
\text { MEZON } \\
\text { (MOBITEL) }\end{array}$ & 23 & 0.8 & $\begin{array}{c}\text { Apogee Alta U9 (ON Semi KAF- } \\
\text { 09000) }\end{array}$ & $3056 \times 3056$ & 12 & 3.0 & $\begin{array}{c}6.76 \\
(2.6 \times 2.6)^{\circ}\end{array}$ & Alt-azimuth & 2 & No. \\
\hline \begin{tabular}{|c|} 
RI MAO: \\
TVT (MOBITEL) \\
\end{tabular} & 4.8 & 0.135 & Watec LCL 902H & $752 \times 582$ & 8.3 & 12.2 & $\begin{array}{c}5.20 \\
(2.6 \times 2)^{\circ}\end{array}$ & Alt-azimuth & 2 & No. \\
\hline \begin{tabular}{|c|} 
RI MAO: \\
FRT \\
\end{tabular} & 30 & 1.5 & $\begin{array}{c}\text { Apogee Alta U9 (ON Semi KAF- } \\
09000)\end{array}$ & $3056 \times 3056$ & 12 & 1.6 & $\begin{array}{c}1.96 \\
(1.4 \times 1.4)^{\circ} \\
\end{array}$ & Alt-azimuth & 2 & No. \\
\hline $\begin{array}{l}\text { RI MAO: } \\
\text { AFU-75 }\end{array}$ & 28 & 0.75 & $\begin{array}{c}\text { Apogee Alta U9 (ON Semi KAF- } \\
09000)\end{array}$ & $3056 \times 3056$ & 12 & 3.3 & $\begin{array}{c}7.84 \\
(2.8 \times 2.8)^{\circ}\end{array}$ & Alt-azimuth & 2 & No \\
\hline $\begin{array}{l}\text { LSR UzhNU: } \\
\text { ChV-400 }\end{array}$ & 40 & 1.75 & $\begin{array}{c}\text { FLI PL09000 (ON Semi KAF- } \\
\text { 09000) + BVR filters } \\
\end{array}$ & $3056 \times 3056$ & 12 & 1.43 & $\begin{array}{c}1.44\left(1.2^{\circ} \mathrm{x}\right. \\
\left.1.2^{\circ}\right) \\
\end{array}$ & Equatorial & 2 & Yes \\
\hline $\begin{array}{c}\text { LSR UzhNU: } \\
\text { Takahashi } \\
\text { BRC-250M }\end{array}$ & 25 & 1.268 & $\begin{array}{c}\text { Apogee Alta F16M(ON Semi } \\
\text { KAF-16803) }\end{array}$ & $4096 \times 4096$ & 9 & 1.46 & $\begin{array}{c}2.76 \\
\left(1.7^{\circ} \times 1.7^{\circ}\right)\end{array}$ & Equatorial & 2 & Yes \\
\hline $\begin{array}{l}\text { AO LNU: } \\
\text { Jupiter-9 } \\
\text { @Meade }\end{array}$ & 5.6 & 0.085 & CCTV WAT- $902 \mathrm{H} 2$ & $752 \times 582$ & $8.6 \times 8.3$ & 20.1 & $\begin{array}{c}13.76 \\
\left(3.2^{\circ} \times 4.3^{\circ}\right)\end{array}$ & Alt-azimuth & 2 & No \\
\hline $\begin{array}{l}\text { AO LNU: } \\
\text { Uran-9 }\end{array}$ & 10 & 0.25 & CCTV LCL 902K & $756 \times 592 \mathrm{~s}$ & $6.69 \times 6.69$ & 6.7 & $\begin{array}{c}1.54 \\
\left(1.1^{\circ} \times 1.4^{\circ}\right)\end{array}$ & $\begin{array}{c}\text { Alt-azimuth / } \\
\text { 4-axis }\end{array}$ & 2 & Yes \\
\hline $\begin{array}{l}\text { AO LNU: } \\
\text { AZT-14 }\end{array}$ & 48 & 7.715 & Trius SX-35 & $4008 \times 2672$ & $9 \times 9$ & 0.23 & $\begin{array}{c}0.045 \\
\left(15.5^{\prime} \times 10.4^{\prime}\right) \\
\end{array}$ & Equatorial & - & No \\
\hline $\begin{array}{l}\text { AO LNU: } \\
\text { GLD-250 }\end{array}$ & 25 & 1.250 & SXV-M9 (Sony ICX423AL) & $752 \times 582$ & $11.6 \times 11.2$ & 1.8 & $\begin{array}{c}0.12 \\
\left(24^{\prime} \times 18^{\prime}\right)\end{array}$ & Equatorial & - & No \\
\hline $\begin{array}{l}\text { MAO NASU: } \\
\text { KIT }\end{array}$ & $\begin{array}{l}35.6(14 \\
\text { inch) }\end{array}$ & 3.190 & $\begin{array}{c}1 \text { camera: QHY-174M GPS (Sony } \\
\text { 1/1.2" CMOS IMX174LU / } \\
\text { IMX174LQJ); } \\
2 \text { camera: SBIG ST-8XME (ON } \\
\text { Semi KAF-1603ME) }\end{array}$ & $\begin{array}{l}1 \text { camera: } \\
1920 \times 1200 \\
2 \text { camera: } \\
1530 \times 1020\end{array}$ & $\begin{array}{c}1 \text { camera: } \\
5.86 \\
2 \text { camera: } \\
9\end{array}$ & $\begin{array}{l}1 \text { camera: } 0.94, \\
\text { bin } 3 \\
2 \text { camera: } 1.44, \\
\text { bin } 3\end{array}$ & $\begin{array}{c}1 \text { camera: } \\
0.017 \\
\left(10^{\prime} \times 6.25^{\prime}\right) \\
2 \text { camera: } \\
0.028 \\
\left(12.3^{\prime} \times 8.2^{\prime}\right)\end{array}$ & Equatorial & 2 & Yes. \\
\hline $\begin{array}{l}\text { MAO NASU: } \\
\text { CST }\end{array}$ & 5.6 & 0.085 & CCTV WAT-902H2 & $\begin{array}{l}752 \times 582 \\
\text { pixels }\end{array}$ & $8.6 \times 8.3$ & 20 & $\begin{array}{c}13.46 \\
\left(4.25^{\circ} \times 3.17^{\circ}\right)\end{array}$ & Alt-Azimuth & 2 & No. \\
\hline $\begin{array}{c}\text { AAO: } \\
\text { Zeiss-600 }\end{array}$ & 600 & 2,4 & ON Semi KAF-09000 & $3000 \times 3000$ & 12 & 1,03 & 0,72 & Equatorial & 0,5 & yes \\
\hline $\begin{array}{l}\text { AAO: } \\
\text { S-600 }\end{array}$ & 600 & 1,16 & KAF-16803 & $4000 \times 4000$ & 9 & 1,6 & 3,16 & $\begin{array}{l}\text { Equatorial } \\
\text { fork }\end{array}$ & 0,5 & yes \\
\hline
\end{tabular}


Such data are calculated for:

- instrumental coordinates of the reference stars in the system matrix Radially symmetric Gaussian as PSF function;

- Cross-identification with usage UCAC4, GAIA DR1,2 as Reference catalogues;

- Performing astrometrical reductions for equatorial coordinates of objects. The connection model between the tangential and the instrumental coordinates - polynomial 4th order.

\section{Network Activity Results}

\subsection{Ephemeris Support}

The UMOS uses several software complexes for the estimation of measurements quality, the estimation of the mean orbital elements, orbit propagation, comparison position and velocity and planning observations of artificial satellites. They were developed in separate research groups at different times.

- Kepler Orbita4 developed at 2006 by joint efforts of Mykolaiv and Odessa observatories leading by Alexander Bazey. Soft is used for determination of Kepler orbital elements (a, e, i, $\Omega, \omega, \mathbf{M}_{0}$ ) (Bazyey et al., 2005).

- Software for orbit determination of objects on GEO and MEO was developed by Igor Kara at 2014 as the joint software Mykolaiv-Odessa. The results of orbit determination can be present as TLE and CPF formats (Bazyey \& Kara, 2009).

- At 2017 Mykolaiv-Kharkiv developed program for the correction of orbital elements in TLE format by Valery Yamnitsky (Reznichenko et al., 2001).

- The Kotlin Orbit Estimation Library (KOrbEstLib) was developed by Leonid Shakun (Shakun, 2018). KOrbEstLib uses Orekit (orekit.org) orbit propagation algorithms and introduces own the models of measurements and orbit determination algorithms. KOrbEstLib supports read and write many various data formats for raw measurements and ephemeris. It is used for the estimation of measurements quality, mean orbital elements and orbit propagation of artificial satellites.

Most of the software for ephemeris support of positional observations (RA, Dec) of artificial satellites was developed about 10-20 years ago and needs to be refreshed. At present, the KOrbEstLib uses in the experimental mode and needed further development.

\subsection{Observational Results}

During nearly ten years the members of UMOS observed more than 3800 artificial space objects during 1133 nights. The best was 2020 year when there was 160 clear nights and 725 objects were observed.

To assess the quality of optical observations of the satellites by the UMOS networkKOrbEstLib was used. For this purpose, our observations of 12 reference satellites at GSO and MEO were compared with the ephemeris of the ILRS and GNSS networks were compared. For all observation stations and for each satellite, estimates of the average residuals were obtained, as well as estimates of the standard deviation of one measurement along and across the visible trajectory. It was found that in the measurements of all stations there are systematic shifts along the apparent path of the satellite. A joint analysis of measurements of satellites in different orbits showed that errors along the apparent path are associated with errors in estimating the time moments corresponding to the measurements. This offset can be eliminated by adjusting the time of the measurement instants by a fixed value for each station. At all stations, small systematic shifts and trends of residuals across the apparent path of the satellite were revealed.

Table 2: Statistics of the observations

\begin{tabular}{|l|c|c|c|c|c|}
\hline Year & $\begin{array}{c}\text { Number of } \\
\text { satellites }\end{array}$ & $\begin{array}{c}\text { Number of } \\
\text { sets }\end{array}$ & $\begin{array}{c}\text { Number of } \\
\text { positions }\end{array}$ & $\begin{array}{c}\text { Observatio- } \\
\text { nal time } \\
\text { (minutes) }\end{array}$ & $\begin{array}{c}\text { Number of } \\
\text { nights }\end{array}$ \\
\hline 2011 (tests) & 79 & 271 & 1558 & 784 & 10 \\
\hline 2012 & 325 & 1859 & 63351 & 49049 & 95 \\
\hline 2013 & 318 & 2417 & 48380 & 52130 & 108 \\
\hline 2014 & 260 & 3633 & 52703 & 19437 & 118 \\
\hline 2015 & 315 & 2381 & 37600 & 12605 & 114 \\
\hline 2016 & 119 & 606 & 10540 & 1341 & 28 \\
\hline 2017 & 416 & 3234 & 63034 & 3819 & 123 \\
\hline 2018 & 442 & 2650 & 61563 & 3589 & 154 \\
\hline 2019 & 374 & 3102 & 63102 & 5924 & 130 \\
\hline 2020 & 725 & 5821 & 117157 & 142721 & 160 \\
\hline 2021 (partially) & 712 & 5776 & 243722 & $11984+$ & 252 \\
\hline
\end{tabular}



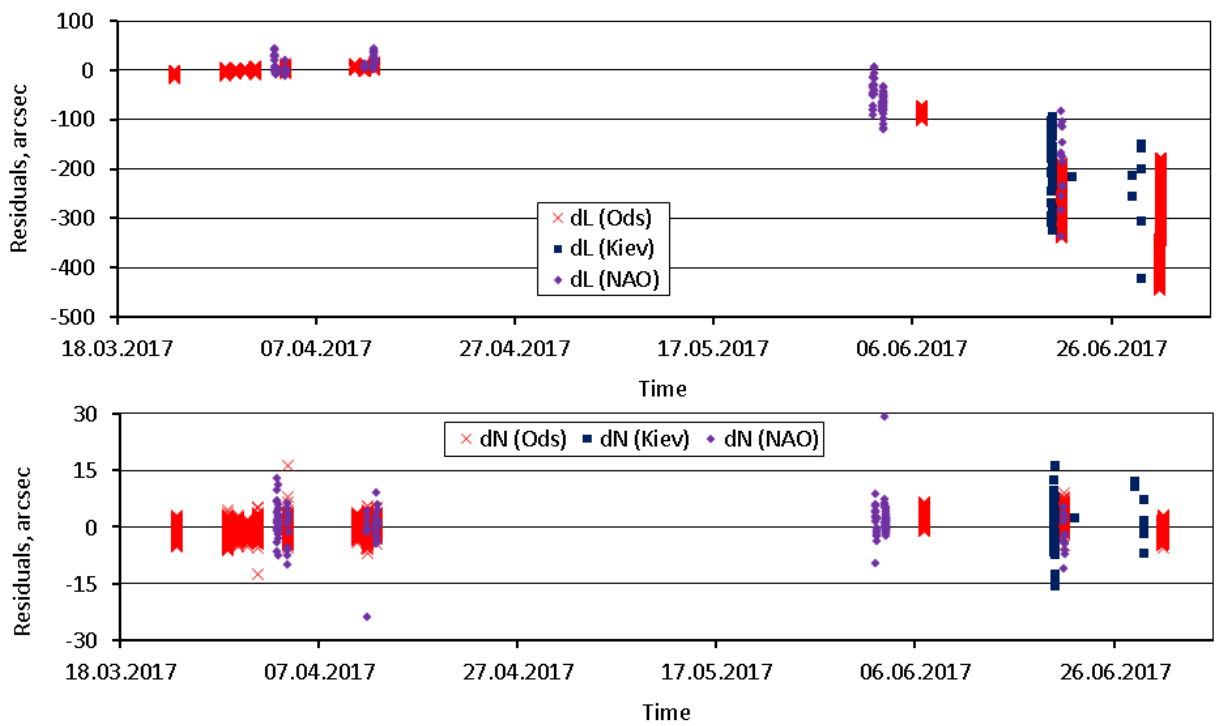

Figure 1: Residuals (in arcsec) between the forecast according to the calculated numerical orbit of Ajisai and observations of UMOS stations (Odessa, Kyiv and Mykolaiv) - along (upper panel) and across the trajectory (bottom panel).
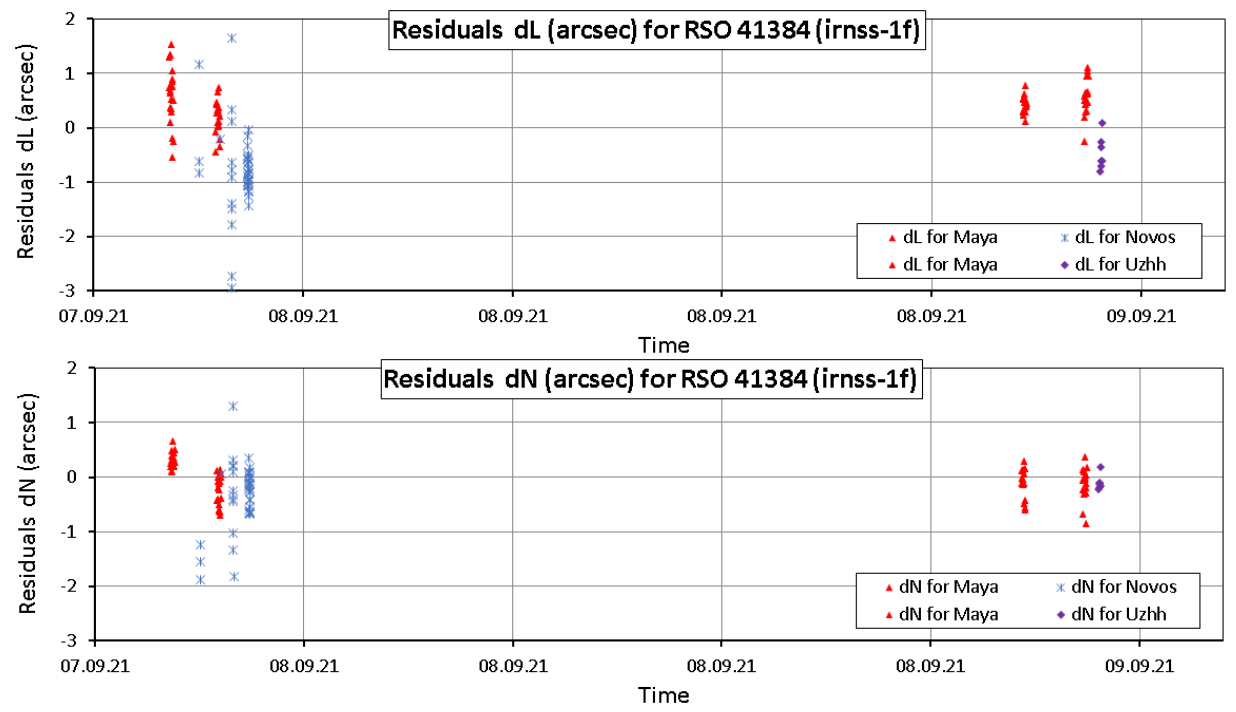

Figure 2: Residuals (in arcsec) between the forecast by ILRS (ISR) orbit of GSS satellite Irnss-1f (41384) and observations of UMOS stations: Mayaki (AO ONU), Novosilki (NSFCTC) and Uzhhogod (LSR UzhNU) -along (upper panel) and across (bottom panel) the trajectory.

It was found that in the short forecast interval (2-4 weeks) the filtered residues for all stations do not have a significant trend. But at greater time intervals, the residuals along the orbit increase almost linearly as the scatter increases. At the same time, the plane of the orbit is predicted by the program OrbEstLab quite satisfactorily at time intervals of at least 2 months. In Fig. 1. are given residuals (in arcseconds) for LEO object Ajisai between the forecast according to our calculated numerical orbit based on observations of UMOS stations and subsequent observations in 2017.

During 2021, several sessions of synchronous (quasisimultaneous) observations of several LEO objects in different orbits were carried out. The aim of this campaign is to improve the method for predicting the movement of LEO objects based on synchronous observations from several separated stations. At the same time, the internal and average external measurement accuracies at each station were refined by comparing the measurements with the predicting for LEO objects, which are tracked by the SLR and navigation networks. Shown below are the residuals between the UMOS measurements and the ILRS ephemeris for the geostationary navigation satellite IRNSS-1f (41384), obtained on September 7 and 8, 2021 are shown (Figure 2).

Instrument capabilities and interior precision of observations are shown at the Table 3. 
Table 3: Observational precisions

\begin{tabular}{|c|c|c|c|c|}
\hline $\begin{array}{c}\text { Observator } \\
\text { y }\end{array}$ & Telescope & Orbit type & mag & errors $(\boldsymbol{\alpha}, \boldsymbol{\delta})$ [“] \\
\hline RI "MAO" & KT-50 & LEO,MEO,GEO & $9 \div 14$ & $\pm(0.5 \div 0.8)$ \\
\hline RI “MAO" & AFU-75 & LEO,MEO,GEO & $9 \div 13$ & $\pm(0.8 \div 1.5)$ \\
\hline RI "MAO" & MEZON & LEO,MEO,GEO & $9 \div 12$ & $\pm(0.8 \div 1.5)$ \\
\hline RI AO ONU & OMT-800 & MEO,GEO & $9 \div 18$ & $\pm(0.3 \div 1.0)$ \\
\hline RI AO ONU & KT-50 & LEO & $2 \div 11$ & $\pm(0.5 \div 1.0)$ \\
\hline RI “MAO" & TV & LEO & $4 \div 11$ & $\pm(2.5 \div 4.0)$ \\
\hline MAO NASU & CST & LEO & $5 \div 10$ & $\pm(2.5 \div 4.0)$ \\
\hline AO LNU & Jupiter-9@Meade & LEO & $4 \div 9$ & $\pm(4.5 \div 5.5)$ \\
\hline LSR UzNU & TPL 1M (guide) & LEO & $4 \div 9$ & $\pm(4.5 \div 5.5)$ \\
\hline
\end{tabular}

\subsection{Photometry of some 'Cosmos' series spacecraft}

For several years the UMOS has been carrying out photometric observations of low-orbit spacecraft of the 'Cosmos' series. Functioning spacecraft have light curves with small non-periodic fluctuations, which are characteristic of an object stabilized in space. Not working objects (Dead objects) have light-curves quite different. Below are two examples of light curves obtained with the KT-50 telescope at the Astronomical Observatory of Odessa University for non-working spacecraft.

The LEO object 2014-086A (40358, Lotos-S1-1 or COSMOS-2502) moves at an altitude of $920 \mathrm{~km}$ above the Earth. The light curve has a noticeable periodic character with large brightness fluctuations, which may indicate the state of free rotation of this spacecraft around the center of mass (Figure 3).

Our measurements for previous years allow us to conclude that this spacecraft is gradually increasing the angular velocity of rotation and, accordingly, the apparent period of brightness fluctuations decreases, as illustrated in the graph below. This most likely indicates that this spacecraft is already rotating as uncontrollable, under the influence of natural cosmic factors - the drag torques of the upper atmosphere and solar pressure, which lead to its unwinding.

The 2013-032A spacecraft (39194, Kondor-E1 or Cosmos-2487), moving at an altitude of about $450 \mathrm{~km}$ above the Earth, can also be in a similar state of free rotation (Figure 4). Our long-term photometric monitoring shows that its light curves are periodic. That means this spacecraft is also in an uncontrollable state, and after the initial acquisition of a high rotation frequency, its angular velocity slowly decreases, possibly under the influence of the Earth's magnetic field - the spacecraft rotation in mid2015 was carried out with a visible period of about 7 seconds, in September 2019 - with a period of 12 seconds, and in July 2021 - with a period of 14.2 seconds.

RSO Cosmos-2502 (14086A, 40358), KT-50 (Ods), 2021-07-01

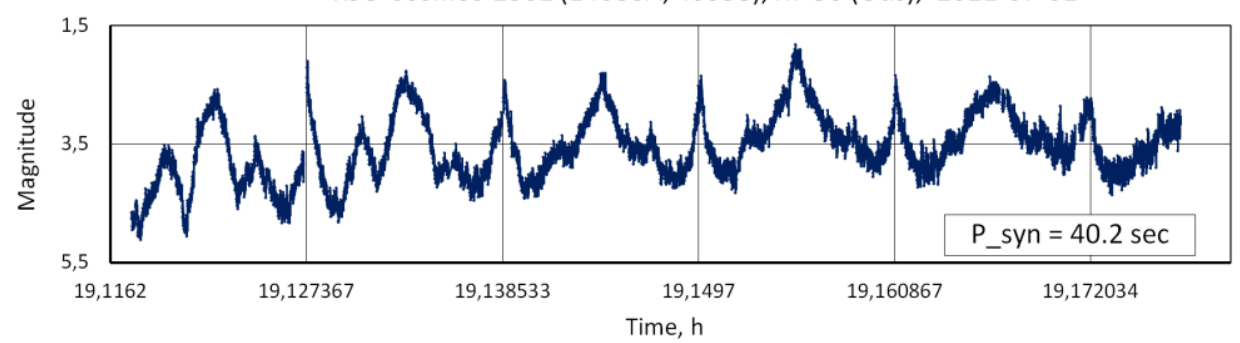

Figure 3: Light curve of Cosmos-2502 spacecraft obtained with the tracking telescope KT-50 (Odessa) on July 1, 2021 at $19 \mathrm{~h} 07 \mathrm{~m}$ UTC during about 3.6 minutes.

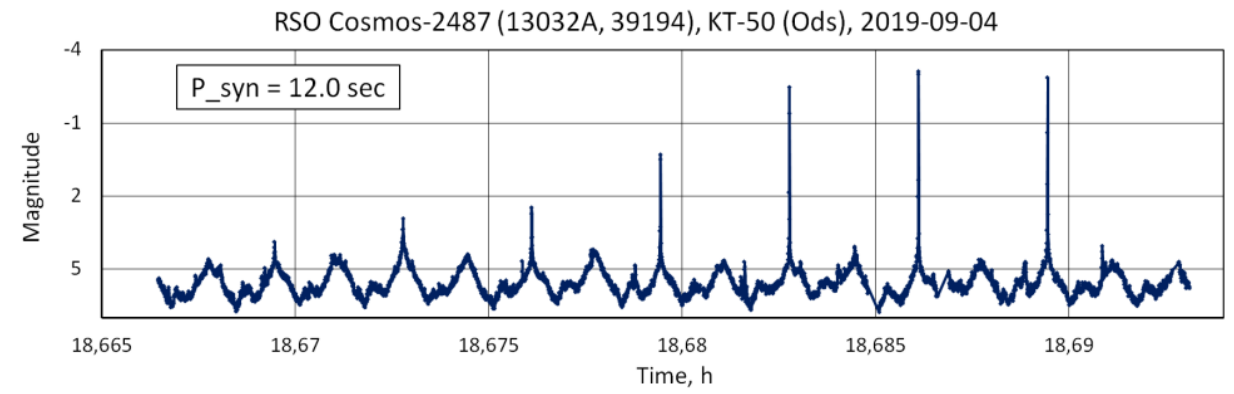

Figure 4: The light curve of the Cosmos-2487 spacecraft obtained with the tracking telescope KT-50 (Odessa) on September 4, 2019 at 18h 40m UTC during about 100 seconds. 

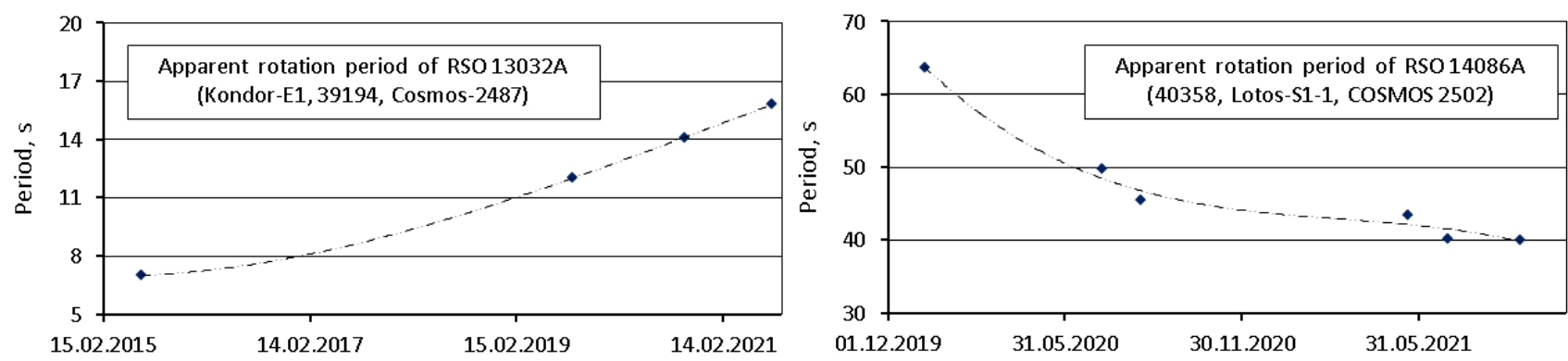

Figure 5: Changes in the apparent rotation period of the Cosmos-2487 and the Cosmos-2502 spacecrafts, obtained during long-term photometric monitoring.

In Fig. 5 are shown changes in the apparent period of two inoperative spacecraft rotation (Kosmos-2487 and Kosmos-2502), obtained during long-term photometric monitoring. The reasons for the high rotation speed after the spacecraft failure can consist either in external influence (impact of space debris), or in the failure of one of the gyroscopes of the attitude control system. Subsequent deceleration of the spacecraft rotation is characteristic of most LEO objects. Nevertheless, for many asymmetric shape LEO objects, an increase in the rotation speed is observed, as for Kosmos-2502.

\section{Conclusion}

The experience of UMOS and main results obtained by UMOS can be considered as the next step to create the SSA of Ukraine. So:

- The network of optical stations has been in operation since 2012 and their results one can find on the UMOS site (UMOS site). Based on the observations can be resolved scientific and applied problems.

- Potentially 24 telescopes at the 7 organizations could be used. Moreover, most of them can observe the artificial objects every clear night.

- The OrbEstLab program based on KOrbEstLib library allows one to approximate the joint observations of LEO debris objects by the UMOS stations over an interval of 1 to 2 weeks with an accuracy of astrometric observation errors.

- For intervals of about 2 months, the OrbEstLab program allows predicting the apparent positions of not working LEO debris satellites with a delay (lead) of the object up to a few seconds of time relative to the ephemeris.

- New methods of observations and new equipment could be developed and implemented if there would be such task, appropriate funding and understanding of the importance of Ukraine's awareness of the space situation.

Acknowledgements. We gratefully thank to the special program for space research at the National Academy of Sciences of Ukraine and its head academician Yaroslav Yatskiv for support of observations for the UMOS work during years. Observations of some people were supported by the National Space Facilities Control and Tests Center of State Space Agency of Ukraine and they are thankful for that.

\section{References}

ESA's Annual Space Environment Report. ESA Space Debris Office. [online], 27 May 2021. Available at: https://www.sdo.esoc.esa.int/environment_report/Space _Environment_Report_latest.pdf [Accessed 2 November 2021].

Space Situational Awareness -> Detecting Space Hazards. [online]. December 2017 by ESA. Available at: https://esamultimedia.esa.int/multimedia/publications/ BR-338/BR-338.pdf [Accessed 2 November 2021].

Vallado D.A., Griesbach Ja.D. Simulating Space Surveillance Networks. Advances in Astronautical Sciences, 11.

UMOS - Ukrainian network of optical stations for nearEarth space research. [online] Available at http://mao.uran.ua/umos_el [Accessed 10 November 2021].

Shulga A.V., Kravchuk S.G., Sybiryakova Ye.S. et al.: 2015, Space Sci. \& Technol., 21, No3, 74. https://doi.org/10.15407/knit2015.03.074

Koval'chuk, M.M., Hirnyak, M.B., Baran, O.A. et al.: 2017, Kinemat. Phys. Cel. Bod., 33, 245. https://doi.org/10.3103/S0884591317050038

Patent 116522 UKRAINE. G02B 23/16 (2006.01). Receiving channel for the mobile laser ranging telescope /Blagodyr Ya.T., Bilinsky A.I., Vovchyk Ye.B., MartyniukLototskiy K.P., Pidstryhach I.Ya., Stodilka M.I., YankivVitkovska L.M. 25.05.2017, Bull. № 10.

Patent 116724 UKRAINE. G02B 23/16 (2006.01). Method of observing space objects /Kovalchuk O.M., Shulga O.V. 25.05.2017, Bull. № 10.

Patent 118001 UKRAINE. G06T 7/00 H04N 5/30 (2006.01). A method of observing low-orbit Earth's satellites and reference stars /Kozyrev Ye.S. 10.07.2017. Bull. №13.

Kozyrev E., Shulga A., Sibiryakova E. et al.: 2007, in Proc. of the International Conf. "Near-Earth Astronomy 2007" (in Russian). Terskol, Russia. 326. ISBN 978-5-93680-195-2. Available at http://www.spsl.nsc.ru/FullText/konfe/Terskol2007.pdf 
Astrometrica - shareware for research grade CCD Astrometry. [online]. Available at http://www.astrometrica.at [Accessed 14 October 2021].

Bazyey O.A., Sibiryakova E.S., Shulga A.V.: 2005, Odessa Astron. Publ., 18, 8.

Bazey A.A. \& Kara I.V.: 2009, Astron. School's Rep., 6 (2), 155. doi: https://doi.org/10.18372/2411-6602.06.2155

Reznichenko A.M., Yamnitsky V.A., Zyubin V.I., Mishura I.I.: 2001, in Proc. of Conf. "Extension and Connection of Reference Frames Using Ground Based CCD Technique” /Ed. G.Pinigin, Oct. 10-13, 2001, Nikolaev, AROL. 173.

Sybiryakova, Ye.S., Shulga, O.V. et al.: 2017, Sci. Innov., 13 (1), 10. doi: https://doi.org/10.15407/scine13.01.010

Shakun L.S. \& Koshkin N.I.: 2014, Adv. in Space Res., 53 (12), 1834.

Shakun L.S.: 2018, Odessa Astron. Publ., 31, 191.

Kaminski K., Koshkin N. et al.: 2017, in Proc. 7th Eur. Conf. on Space Debris, ESA/ESOC, Darmstadt, Germany.

(https://conference.sdo.esoc.esa.int/proceedings/sdc7/p aper/721/SDC7-paper721.pdf)
Kozhukhov O.M., Rishchenko S.V. et al.: 2019, Uzhhorod University Scientific Herald. Series Physics. 45, 141. DOI 10.24144/2415-8038.2019.45.141-148.

Epishev V.P. et al.: 2018. Uzhhorod University Scientific Herald. Series Physics. 43, 54-62. DOI: 10.24144/2415-8038.2018.43.54-62.

Koshkin, N., Savanevich, V. et al.: 2017, Odessa Astron. Publ., 30, 226. DOI: $10.18524 / 1810-$ 4215.2017.30.117655

Koshkin N., Shakun L. et al.: 2020, Odessa Astron. Publ., 33, 191. https://doi.org/10.18524/18104215.2020.33.216464

Troianskyi V., Kashuba V., Krugly Yu.: 2019, The Minor Planet Bull., 46, 2, 109.

http://adsabs.harvard.edu/abs/2019MPBu...46..109T

Kozhukhov O.M. et al.: 20206 in Proc. of $20^{\text {th }} \mathrm{Adv}$. Maui Optical and Space Surveillance Techn. Conf. https://amostech.com/TechnicalPapers/2020/Poster/Koz hukhov.pdf. 